\title{
Teacher Candidates' Anxieties Regarding Facebook Usage in Education
}

\author{
Mehmet Ramazanoğlu ${ }^{1}$, Esef Hakan Toytok ${ }^{2}$ \\ ${ }^{1}$ Asst. Prof. Dr., Siirt University, Faculty of Education, Computer Education and Instructional Technology Department, \\ Turkey \\ ${ }^{2}$ Asst. Prof. Dr., Siirt University, Faculty of Education, Educational Sciences Department, Turkey \\ Correspondence: Esef Hakan Toytok, Asst. Prof. Dr., Siirt University, Faculty of Education, Educational Sciences \\ Department, Turkey.
}

Received: October 9, 2018

doi:10.11114/jets.v6i11a.3820
Accepted: November 1, $2018 \quad$ Online Published: November 29, 2018

URL: https://doi.org/10.11114/jets.v6i11a.3820

\begin{abstract}
The aim of this research is to determine the anxiety levels of teacher candidates regarding Facebook usage in education and analyse it according to various variables. In the research, descriptive survey model was used which is one of the quantitative research methods. The population of the research includes 184 teacher candidates who are receiving education in the Department of Computer and Instructional Technologies Education of Siirt University Faculty of Education in 2017-2018 academic year. Since the population is accessible, no attempt has been made for sampling. Facebook Usage Anxiety in Education (FUAE) scale was used as data collection inventory in the study. According to results obtained in the research; it was seen that the anxiety levels of teacher candidates were high while using Facebook, Facebook usage anxiety had no significant difference with respect to class and age independent variables; however, there was a meaningful difference with respect to gender independent variable.
\end{abstract}

Keywords: facebook, teacher candidate, anxiety, facebook in education

\section{Introduction}

Policies concerning education training are now being transformed into a sustainable structure. Accordingly, it can be seen that many models and theories have been developed by researchers. Undoubtedly, technological developments and changes are seen as the main catalyst for the change in these education policies. For this reason, rapid developments in information sharing and communication technologies have also had an impact on the educational processes and educational environments. Social networks of which users are increasing every day as a part of these technologies have begun to shape communication, sharing, interaction, work and learning processes of the people. Social networks provide users with the opportunity to share easily and quickly. In addition, social network is a platform which provides its users with the opportunity to share their personal information including ideas, activities and interests as well as their communication and social relationship information with other people through their networks (Jones, Blackey, Fitzgibbon \& Chew, 2010; Tiryakioğlu \& Erzurum, 2011). In this way, social network users can define themselves in community life and interact with other people who are interested in the same area, and they can also selectively block people with whom they do not want to interact (Boyd \& Ellison, 2007; Kwon \& Wen, 2010).

In educational environments, social networks improve communication skills of students and teachers in terms of sustainable learning, facilitate interaction of students with content, provide learning based on research, questioning, problem solving and cooperation skills (Gülbahar, Kalelioğlu \& Madran, 2010; Grant, 2008). Facebook is the most well-known platform among these environments and it is widely used by individuals. Facebook is a virtual platform established in February 2004 and the number of its users is increasing rapidly in the world. This platform is known to be the most used social network today. According to the news reported by Anadolu Agency, the number of active users of Facebook has exceeded 2.13 billion people as of February 2008. Using Facebook has become an ordinary and normal activity in our daily lives. Facebook can also be used widely in education due to its active users (Bumgarner, 2007). In literature, studies about using Facebook in education can be encountered (Kalafat \& Göktaş, 201; McLoughlin \& Lee, 2007; Munoz \& Towner, 2009; Sharma, Joshi \& Sharma, 2016; Usluel, 2016).

Since Facebook platform is a commonly used network, there may be negative outcomes seen such as fraud, accessing the personal account and stealing information. The increase in information sharing in the social environment frightens 
and worries users (Altun \& Kuşkaya, 2008). In addition, Facebook is widely used and appeals to all ages. For these reasons, analyzing the anxiety in teacher candidates regarding Facebook usage in education is also important. The research will also help educators reduce their anxieties while using Facebook.

Within this context, the aim of this research is to determine the anxiety levels of teacher candidates regardingFacebook use for sustainable education and analyse it according to various variables. For this purpose, the following question were tried to be answered in the study:

What is the level of anxiety of teacher candidates related to Facebook use in education?

Do anxiety levels of teacher candidates related to Facebook use in education change significantly in terms of gender, age, and class levels?

\section{Method}

In the research which aims to determine the anxiety level of teacher candidates regardingFacebook use in education and analyse it according to various variables, descriptive survey model was used which is one of the quantitative research methods. Descriptive survey model is a research approach that aims to reveal a situation as it is (Karasar, 2011).

Since the teaching branch that uses computer and related software's more is Computer and Instructional Technology teaching, only teacher candidates to this branch was included in the population of the study (Aric1, 2007). The population of the research includes 184 teacher candidates who are receiving education in the Department of Computer and Instructional Technologies Education of Siirt University Faculty of Education in 2017-2018 academic year. Since the population is accessible, no attempt has been made for sampling. 152 of the inventories distributed in the research were returned and 19 of them were excluded from the scope of the study because they were not filled in accordance with the guidelines; therefore, opinions of 133 teacher candidates were included in the survey and analysed. Information related to teacher candidates who have participated in the research is presented in table 1.

Table 1. Personal Information of the Students who participated in the Research

\begin{tabular}{cccc}
\hline Variables & & $\begin{array}{c}\text { Number of students } \\
(\mathrm{N}=133)\end{array}$ & $\%$ \\
\hline \multirow{2}{*}{ Gender } & Male & 70 & 52,6 \\
& Female & 63 & 47,4 \\
\multirow{2}{*}{ Age } & 20 and below & 29 & 21,8 \\
& $21-23$ & 71 & 53,4 \\
& 24 and above & 33 & 24,8 \\
\multirow{2}{*}{ Class Level } & 1.Class & 11 & 8,3 \\
& 2.Class & 43 & 32,3 \\
& 3.Class & 40 & 30,1 \\
& 4.Class & 39 & 29,3
\end{tabular}

8-item Facebook Usage Anxiety in Education (FUAE) scale developed by Hamutoğlu \& Yıldız (2016) was used in the study as the data collection tool. FUAE scale is a likert type scale which is coded as, 1: strongly disagree, 2: disagree, 3: undecided, 4: agree, 5: strongly agree. While interpreting the averages, 1,00-1,79 was accepted as strongly disagree, 1,80-2,59 was accepted as disagree, 2,60-3,39 was accepted as undecided, 3,40-4,19 was accepted as agree and 4.205.00 was accepted as strongly agree.

Hamutoğlu \& Yildiz (2016) found the Cronbach's alpha coefficient as .72 to determine the consistency of the scale. In this research, Cronbach alpha coefficient was found as .73. In this context, it is seen that the scale in general is reliable to measure Facebook use anxiety in education.

Frequency, percentage and arithmetic mean were used in the analysis of the scores for Facebook usage anxiety in education. The "Kolmogorov-Smirnov test" procedure was used to show the homogeneity distribution of the data. The "Mann-Whitney U" statistics were used to determine whether there was a significant difference between the scores of Facebook use anxiety in education compared to the "gender and intergroup differences". The "Kruskal Wallis Test" procedure was used to determine whether scores of Facebook use anxiety in education were significant according to age and class variables. The level of significance in the statistical analysis of the scale was determined as" $p<.05$ ". 


\section{Findings}

Findings related to the questions which were tried to be answered in the study were tabulated and presented in this section.

\section{Anxiety Levels of Teacher Candidates Related to Facebook Use in Education}

Standard deviation and percentages belonging to the opinions of teacher candidates related to their anxiety regarding Facebook use in education were shown in Table 2.

Table 2. Averages and standard deviations belonging to the scale items $(\mathrm{N}=133)$.

\begin{tabular}{lrr}
\hline Items & $X$ & $\mathrm{Sd}$ \\
\hline $\begin{array}{l}\text { If my materials such as photos, videos, animations, activities etc. that I used for making the } \\
\begin{array}{l}\text { course content were published on Facebook without my authorization, it would make me } \\
\text { feel uncomfortable. }\end{array}\end{array}$ & 4,24 & 1,19 \\
$\begin{array}{l}\text { Encountering with ads in which I am not interested on my news feed while I am sharing } \\
\text { something on Facebook related to the course makes me worried. }\end{array}$ & 3,87 & 1,14 \\
$\begin{array}{l}\text { The idea that my personal information may be distributed on Facebook makes me feel } \\
\text { orried. }\end{array}$ & 4,12 & 1,12 \\
$\begin{array}{l}\text { The idea that my personal life may be revealed on Facebook makes me uncomfortable. } \\
\text { The idea that someone can steal my Facebook password and user information makes me }\end{array}$ & 4,19 & 1,04 \\
$\begin{array}{l}\text { uncomfortable. } \\
\text { Being online with my friends / students on a social network platform such as Facebook } \\
\text { makes me uncomfortable. }\end{array}$ & 2,91 & 1,10 \\
$\begin{array}{l}\text { The idea of receiving negative message from my students/ friends makes me } \\
\text { uncomfortable. }\end{array}$ & 3,10 & 1,26 \\
$\begin{array}{l}\text { The quality of the content of the subject that I shared via Facebook (its compliance with the } \\
\text { target-behaviors, its quality etc.) makes me uncomfortable. }\end{array}$ & 3,26 & 1,19 \\
\begin{tabular}{l} 
General average \\
\hline
\end{tabular} & 3,71 & \\
\hline
\end{tabular}

When the data in Table 2 are examined, it is seen that the teacher candidates are dispersed at the point of "agree" with their opinions about Facebook use anxiety in education $(\bar{X}=3,71)$. While it is seen that teacher candidates prefer "strongly agree" option for "If my materials such as photos, videos, animations, activities etc. that I used for making the course content were published on Facebook without my authorization, it would make me feel uncomfortable" ( $\bar{X}=$ 4,24), they prefer "'undecided" option for 'Being online with my friends / students on a social network platform such as Facebook makes me uncomfortable" ( $X$ 2.91).

While teacher candidates prefer "agree" option for " Encountering with ads in which I am not interested on my news feed while I am sharing something on Facebook related to the course makes me worried" $(\bar{X}=3,87)$, they prefer "undecided" option for "The idea of receiving negative message from my students/ friends makes me uncomfortable.' $(X=3,10)$

It was seen that teacher candidates preferred "agree" option for "The idea that my personal information may be distributed on Facebook makes me feel worried" $(X=4,12)$. On the other hand, they chose the option "undecided" for " the quality of the content of the subject that I shared via Facebook (its compliance with the target-behaviours, its quality etc.) makes me uncomfortable" ( $\bar{X}=3,26)$. In addition, teacher candidates agree with the statement " The idea that my personal life may be revealed on Facebook makes me uncomfortable" $(X=4,19)$ and statement "the idea that someone can steal my Facebook password and user information makes me uncomfortable" ( $\bar{X}=3,97)$.

The Kolmogorov-Smirnov test results related to the homogeneity distribution of the data obtained in the study are shown in table 3. 
Table 3. Kolmogorov-Smirnov test findings.

\begin{tabular}{|c|c|c|c|c|}
\hline & & Class & Gender & Age \\
\hline \multirow{2}{*}{ Normal Parameters ${ }^{\mathrm{a}, \mathrm{b}}$} & Mean & 2,80 & 1,47 & 2,03 \\
\hline & Std. Deviation & ,957 &, 501 & 0,68 \\
\hline \multirow{3}{*}{ Most Extreme Differences } & Absolute & ,206 &, 354 & 0,26 \\
\hline & Positive & ,206 & ,354 & 0,26 \\
\hline & Negative &,- 187 &,- 327 &,- 26 \\
\hline Kolmogorov-Smirnov Z & & 2,372 & 4,083 & 3,10 \\
\hline Asymp. Sig. (2-tailed) & & 0,00 & 0,00 & 0,00 \\
\hline
\end{tabular}

When Table 3 is examined, it is seen that data distributions do not show normal distribution " $p<.05$ ". Non-parametric statistical methods were used in the study because the significance value was less than .05 .

\section{Analysis of Facebook Use Anxiety of Teacher Candidates in Education with Respect to Gender, Age and Class Level Independent Variables}

The Mann-Whitney U test findings for the average comparison of the teacher candidates' opinions on Facebook use anxiety in education according to gender were presented in Table 4.

Table 4. U-Test findings according to gender

\begin{tabular}{lcccccc}
\hline & Gender & N & Mean Rank & Sum of Ranks & $\begin{array}{c}\text { Mann-Whitney } \\
\text { U }\end{array}$ & P \\
\hline General & Male & 70 & 58,99 & 4129,50 & 1644,50 &, 011 \\
Average & Female & 63 & 75,90 & 4781,50 & &
\end{tabular}

When the findings in Table 4 were examined, it was found that there was a significant difference in the averages in terms of gender $(\mathrm{U}=1644.50, \mathrm{P}<.05)$. When the mean rank is taken into consideration, it is seen that anxiety levels of female teacher candidates are higher than the male teacher candidates.

The results of the Kruskal Wallis Test for the average comparison of the opinions of the teacher candidates related to Facebook use anxiety in education according to their ages are presented in Table 5.

Table 5. Kruskal Wallis test findings according to ages

\begin{tabular}{|c|c|c|c|c|c|c|c|}
\hline \multicolumn{2}{|c|}{ Age } & $\mathrm{N}$ & Mean Rank & $\mathrm{X}^{2}$ & $\mathrm{P}$ & Df & Significant Difference \\
\hline \multirow[t]{3}{*}{ General Average } & 20 and below & 29 & 65,97 & 3,977 & ,13 & 2 & None \\
\hline & $21-23$ & 71 & 72,39 & & & & \\
\hline & 24 and above & 33 & 56,30 & & & & \\
\hline
\end{tabular}

When the findings in Table 5 were examined, score average according to age independent variable was found to be $\mathrm{p}$ $=.13$. For this reason, no significant difference was found for " $p<.05$ ". However, it was observed that there were significant differences among groups for some items (Item3, Item5, Item7) were significantly different among the groups. The Mann-Whitney U test was applied to examine the source of this difference. The data related these findings are presented in tables 6,7 and 8 .

Table 6. Mann-Whitney U test findings age group 20 and below and 21-23

\begin{tabular}{lllcccc}
\hline & \multicolumn{1}{c}{ Age } & $\mathrm{N}$ & Mean Rank & Sum of Ranks & $\mathrm{U}$ & $\mathrm{P}$ \\
\hline \multirow{2}{*}{ Item3 } & 20 and below & 29 & 52,55 & 1524,00 & 970,000 &, 61 \\
& $21-23$ & 71 & 49,66 & 3526,00 & & \\
\multirow{2}{*}{ Item5 } & 20 and below & 29 & 50,88 & 1475,50 & 1018,500 &, 92 \\
& $21-23$ & 71 & 50,35 & 3574,50 & & \\
\multirow{2}{*}{ Item7 } & 20 and below & 29 & 39,07 & 1133,00 & 698,000 &, 01 \\
& $21-23$ & 71 & 55,17 & 3917,00 & & \\
\hline
\end{tabular}


Table 7. Mann-Whitney $U$ test findings for age group 20 and below and 24 and above

\begin{tabular}{lllcccc}
\hline & Age & $\mathrm{N}$ & Mean Rank & Sum of Ranks & $\mathrm{U}$ & $\mathrm{P}$ \\
\hline \multirow{2}{*}{ Item3 } & 20 and below & 29 & 37,14 & 1077,00 & 315,000 &, 01 \\
& 24 and above & 33 & 26,55 & 876,00 & & \\
\multirow{2}{*}{ Item5 } & 20 and below & 29 & 36,91 & 1070,50 & 321,500 &, 02 \\
& 24 and above & 33 & 26,74 & 882,50 & & \\
\multirow{2}{*}{ Item7 } & 20 and below & 29 & 28,31 & 821,00 & 386,000 &, 17 \\
& 24 and above & 33 & 34,30 & 1132,00 & &
\end{tabular}

Table 8. Mann-Whitney U test findings for age group 21-23 and 24 and above

\begin{tabular}{clccccc}
\hline & Age & N & Mean Rank & Sum of Ranks & U & P \\
\hline \multirow{2}{*}{ Item3 } & $21-23$ & 71 & 57,46 & 4079,50 & 819,500 &, 00 \\
& 24 and above & 33 & 41,83 & 1380,50 & & \\
\multirow{2}{*}{ Item5 } & $21-23$ & 71 & 58,30 & 4139,00 & 760,000 &, 00 \\
& 24 and above & 33 & 40,03 & 1321,00 & & \\
\multirow{2}{*}{ Item7 } & $21-23$ & 71 & 54,76 & 3888,00 & 1011,000 &, 24 \\
& 24 and above & 33 & 47,64 & 1572,00 & & \\
\hline
\end{tabular}

When the findings in Tables 6, 7 and 8 are examined, it can be seen that 'The idea of receiving negative message from my students/ friends" creates anxiety at a significant level for the age group 21-23 compared to the age group 20 and below. On the other hand, "the idea that my personal life may be revealed on Facebook" and "the idea that someone can steal my Facebook password and user information" create anxiety at a significant level between 20 and blow and 21-23 age groups as well as between age group 24 and above and 21-23.

The Kruskal Wallis Test findings for the average comparison of the teacher candidates' opinions on Facebook use anxiety in education according to class levels were presented in Table 9.

Table 9: Kruskal Wallis result according to class levels ( $\mathrm{N}=133),(\mathrm{P}>.05)$.

\begin{tabular}{rrrccccc}
\hline Class levels & & $\mathrm{N}$ & Mean Rank & $\mathrm{X}^{2}$ & $\mathrm{P}$ & $\mathrm{Df}$ & Significant Difference \\
\hline \multirow{3}{*}{ General Average } & 1 & 11 & 70,73 & & & & \\
& 2 & 43 & 64,29 & & & \\
& 3 & 40 & 71,55 & 1,07 &, 78 & 3 & None \\
& 4 & 39 & 64,27 & & & & \\
\hline
\end{tabular}

When the findings in Table 6 were examined, score average according to class level independent variable was found to be $p=.78$. For this reason, no significant difference was found regarding the anxiety level of teacher candidates related to Facebook use according to class levels " $p<.05$ ".

\section{Results, Conclusions and Recommendations}

According to the results obtained from the research, it was determined that the teacher candidates had a high level of anxiety related to Facebook use in education. Particularly, it is seen that they are highly concerned about the information reliability. According to this, it can be said that the teacher candidates do not see Facebook as a valid and safe social platform for using it in education. Raynes-Goldie (2010) expressed similar results, saying that the information shared on Facebook is beyond the control of users once it is shared. Ac1lar \& Mersin (2015) in their study stated that the most significant reason for not using Facebook is the concern that the information shared on the internet can be used with bad intentions according to the people who do not use Facebook.

It was seen that teacher candidates are disturbed on use of the photo / video / animation / activity etc. that they use while creating the course content on Facebook without their permission. The reason behind that is the privacy anxiety, the possibility of information theft and using this information for different purposes. As a result, it is seen in the studies that individuals who have privacy anxiety avoid using social media (Oz, 2014; Young \& Quan-Haase, 2013). In addition, while the teacher candidates share something related to the course on Facebook; they have expressed that they will be uncomfortable if they encounter with advertisements in which they are not interested on their news feed. It can be argued that this is mainly due to the prevalent opinion that these advertisements contain viruses. 
According to another result obtained in the study, it has been seen that teacher candidates worry that their personal information may be revealed and distributed via Facebook, their private life may be exhibited on Facebook, and they are disturbed by the idea that someone can steal their Facebook user information and passwords. It could be considered that the reason of this situation is the negative events such as increasing amount of virtual fraud, unauthorized access to personal account and information theft in recent times.

In the study conducted by $\mathrm{Oz}$ (2014), it was stated that social media users are hesitant to exhibit personal information and share it with others because of the possibility of information theft. In parallel, Saeri, Ogilvie, La Macchia, Smith, \& Louis (2014) stated in their research that personal photographs which can put individuals in a difficult position can be distributed to others on the internet and identity information can be stolen and used for fraud.

According to the results obtained related to classroom-level, gender and age independent variables in the study, significant difference was found with respect to gender variable while there was no significant difference in Facebook usage anxiety in education with respect to classroom-level and age-independent variables. When the source of the significant difference was looked at, it was seen that female teacher candidates had a higher level of Facebook usage anxiety in education compared to the male candidates.

According to this, it can be said that female teacher candidates show a higher level of sensitivity in terms of protecting their privacy; therefore, they are more careful and selective compared to the male teacher candidates. Studies conducted by Saeri et al. (2014) and Fogel \& Nehmad (2009) revealed similar results which indicate that female social media users are more concerned about privacy than male users and that they are more cautious when using the social media.

A different result obtained from the study showed that teacher candidates in the higher age group are more disturbed with the idea of receiving negative message from their students/ friends. It is also observed that teacher candidates in this age group fear and worry about that their Facebook user information and passwords can be stolen by someone else. The reason behind that could be the fact that as the age level of the teacher candidates increases, they attach more importance to privacy. Similar results can also be seen in the study conducted by at Litt (2013) which shows that as the age level of the virtual network users increase, they attach more importance to privacy and private life.

As a result, teacher candidates should be able to use commonly-used networks such as Facebook more effectively for sustainable education because information technologies and related social network software are becoming more and more widely used in education every day. The education and training process becomes more interactive and dynamic thanks to these networks. However, problems of the users such as security and privacy should be dealt with and solved in a way that it will comfort the users in order to improve these skills.

According to the findings of the research, the following recommendations have been developed for the use of Facebook in education;

- Training can be provided to teacher candidates related to the measures to be taken against problems that they can encounter while using Facebook in education for a sustainable and effective education and training process.

- Teacher candidates can be informed about the practices that need to be taken into consideration for secure social network use.

- Examples of post sharing related to education and training can be developed via Facebook

\section{References}

Acılar, A., \& Mersin, S. (2015). Üniversite öğrencilerinin Facebook kullanımı ile mahremiyet kaygısı arasındaki ilişki. Elektronik Sosyal Bilimler Dergisi, 14(54). https://doi.org/10.17755/esosder.71918

Altun, A., \& Kuşkaya, M. Y. (2008). Teknofobi bilişim teknolojileri öğretiminde sosyopsikolojik değişkenler, Ed: Deryakulu, D. Ankara: Maya Akademi.

Arıcı, B. (2007). Bilgisayar ve ögretim teknolojileri eğitimi bölümü ögrencilerinin mesleğe yönelik beklentileri ile alanda çalı̧̧an bilgisayar ögretmenlerinin mesleğe yönelik alglları. İzmir:Yayınlanmamış yüksek lisans tezi, Dokuz Eylü lÜniversitesi Eğitim Billimleri Enstitüsü

Boyd, D., \& Ellison, N. (2007). Social network sites: definition, history and scholarship. Engineering Management Review, 38(3). https://doi.org/10.1111/j.1083-6101.2007.00393.x

Bumgarner, B. A. (2007). You have been poked: Exploring the uses and gratifications of Facebook among emerging adults. First Monday, 12(11). https://doi.org/10.5210/fm.v12i11.2026

Fogel, J., \& Nehmad, E. (2009). Internet social network communities: Risk taking, trust, and privacy concerns. Computers in Human Behavior, 25, 153-160. https://doi.org/10.1016/j.chb.2008.08.006 
Grant, N. (2008, March). On the usage of socialnetworking software technologies in distance learning education. In Society for information technology \& teacher education international conference (pp. 3755-3759).

Gülbahar, Y., Kalelioğlu, F., \& Madran, O. (2010). Sosyal ağların eğitim amaçlı kullanımı. XV. Türkiye'de İnternet Konferansı, İstanbul Teknik Üniversitesi, İstanbul

Hamutoğlu, N. B., \& Yıldız, E. P. (2016). Eğitimde Facebook kullanım kaygısı (EFKK): Ölçek geliştirme çalı̧̧ası. Sakarya Üniversitesi Eğitim Fakültesi Dergisi, 32, 54-69.

Jones, N., Blackey, H., Fitzgibbon, K., \& Chew, E. (2010). Get out of my space.Computers and Education, 54(3), 776782. https://doi.org/10.1016/j.compedu.2009.07.008

Kalafat, Ö., \& Göktaş, Y. (2011). Sosyal ağların yüksek öğretimde kullanımı: Gümüşhane Üniversitesi, Facebook Örneği. 5th International Computer \& Instructional Technologies Symposium, FiratÜniversitesi, Elazı̆̆.

Karasar, N. (2011). Bilimsel araştırma yöntemi, Ankara: Nobel Akademik Yayıncıllk

Kwon, O., \& Wen, Y. (2010). An empirical study of the factors affecting social network service use. Computers in Human Behavior, 26 (2), 254-263. https://doi.org/10.1016/j.chb.2009.04.011

Litt, E. (2013). Understanding social network site users' privacytooluse. Computers in Human Behavior, 29, 1649-1656. https://doi.org/10.1016/j.chb.2013.01.049

McLoughlin, C., \& Lee, M. J. V. (2007). Social software and participatory learning: pedagogical choices with technology affordances in the web 2.0 era, Proceedings ascilite Singapore. Web: http://researchbank.acu.edu.au/cgi/viewcontent.cgi?article=3049\&context=fea_pub

Munoz, C. L., \& Towner, T. L. (2009). Opening Facebook: How to use facebook in the college classroom. Societyfor Information Technology and Teacher Education conference in Charleston, South Carolina. Web: http://www46.homepage.villanova.edu/john.immerwahr/TP101/Facebook.pdf

OZ, M. (2014). Sosyal medya kullanımı ve mahremiyet algısı: Facebook kullanıcılarının mahremiyet endişeleri ve farkındalıkları. Journal of Yaşar University, 9(35), 6245-6254. https://doi.org/10.19168/jyu.96978

Raynes-Goldie, K. (2010). Aliases, creeping and wallcleaning: Understanding privacy in the age of Facebook. First Monday Peer-Reviewed Journal on The Internet, 15, 1-4.

http://firstmonday.org/ojs/index.php/fm/rt/printerFriendly/2775/2432

Saeri, A. K., Ogilvie, C., La Macchia, S. T., Smith, J. R., \& Louis, W. R. (2014). Predicting Facebook users' online privacy protection: Risk, trust, norm focus theory, and the theory of planned behavior. The Journal of Social Psychology, 154(4), 352-369. https://doi.org/10.1080/00224545.2014.914881

Sharma, S. K., Joshi, A., \& Sharma, H. (2016). A multi-analytical approach to predictthe Facebook usage in higher education. Computers in Human Behavior, 55, 340-353. https://doi.org/10.1016/j.chb.2015.09.020

Tiryakioğlu, F., \& Erzurum, F. (2011). Bir eğitim aracı olarak ağların kullanımı. 2nd International Conference on New Trends in Education and Their Implications. Antalya.

Usluel, Y. K. (2016). Social Network Usage. In Social Networking and Education (pp. 213-222). Springer International Publishing. https://doi.org/10.1007/978-3-319-17716-8_13

Young, A. L., \& Quan-Haase, A. (2013). Privacy protection strategies on Facebook. Information, Communication \& Society, 16(4), 479-500. https://doi.org/10.1080/1369118X.2013.777757

\section{Copyrights}

Copyright for this article is retained by the author(s), with first publication rights granted to the journal.

This is an open-access article distributed under the terms and conditions of the Creative Commons Attribution license which permits unrestricted use, distribution, and reproduction in any medium, provided the original work is properly cited. 